\title{
Effect of Temperature and Solvent Composition on the Acid Dissociation Constants of 2-Pyrrol and 2-Thiophene Aldehyde Phenyl Sulphonyl Hydrazones
}

\author{
Refaat I. Nessim¹, Imad E. Albalaa², Mona Abu Assi² \\ ${ }^{1}$ Department of Chemistry, Faculty of Science, University of Cairo, Giza, Egypt \\ ${ }^{2}$ Faculty of Basic Education, Public Authority of Applied Education and Training, Kuwait City, Kuwait \\ Email: refaat_nessim@hotmail.com
}

How to cite this paper: Nessim, R.I., Albalaa, I.E. and Assi, M.A. (2016) Effect of Temperature and Solvent Composition on the Acid Dissociation Constants of 2-Pyrrol and 2-Thiophene Aldehyde Phenyl Sulphonyl Hydrazones. Natural Science, 8, 442-449. http://dx.doi.org/10.4236/ns.2016.810046

Received: December 31, 2015

Accepted: October 28, 2016

Published: October 31, 2016

Copyright $\odot 2016$ by authors and Scientific Research Publishing Inc. This work is licensed under the Creative Commons Attribution International License (CC BY 4.0).

http://creativecommons.org/licenses/by/4.0/ (c) (i) Open Access

\begin{abstract}
Acid dissociation constants, pKa, of 2-pyrrolaldehyde phenylsulphonyl hydrazone, 1, and 2-thiophenealdehyde phenylsulphonyl hydrazone, 2, have been determined spectrophotometrically in ethanol-water media of various compositions over the temperature range $25^{\circ} \mathrm{C}-45^{\circ} \mathrm{C}$. The obtained results were used in the calculation of the enthalpy, $\Delta H^{\circ}$, and the entropy, $\Delta S^{\circ}$, of the ionization processes. The slight variations observed in the $\mathrm{pKa}$ values of the thiophene compound compared to the pyrrol analogue revealed that neither of the two hetero atoms in the pyrrol or thiophene rings, of the two compounds, is involved in a hydrogen bond chelation. This conclusion was also confirmed through measurements of the dipole moment, IR and NMR spectra.
\end{abstract}

\section{Keywords}

Acid Dissociation Constant, Pyrrol, Thiophene

\section{Introduction}

Aldehyde phenylsulphonyl hydrazones of the type, $\mathrm{Ar}-\mathrm{CH}=\mathrm{N}-\mathrm{NH}-\mathrm{SO}_{2} \mathrm{Ph}$, were firstly prepared by Grammaticakis [1]. These compounds were only used as intermediates in the preparation of 5-arseno-sulphonylformazanes [2] and 2, 5-disubstituted tetrazoles [3] [4]. As such compounds showed pronounced acidity, it seemed interesting to prepare compounds 1 and 2 with $\mathrm{Ar}=$ pyrrol and thiophene rings, respectively, in order to investigate the effect of the nitrogen and sulpher hetero atoms, $\mathrm{X}$, on the acidity of 
these derivatives and correlating their acid dissociation constants with the solvent, ethanol-water, composition and temperature, we can also investigate the possibility of metal chelation if the hetero atoms, $\mathrm{X}$, are involved in hydrogen bond formation.

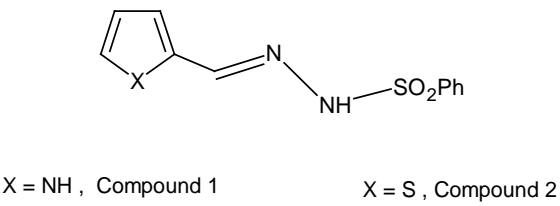

\section{Experimental}

2-pyrrolaldehye phenylsulphonyl hydrazone, 1, and 2-thiophenealdehyde phenylsulphonyl hydrazone, 2, were prepared by the general procedure described elsewhere [4]. Melting points were found to agree with those reported in the literature.

Measurements of $\mathrm{PH}$ were made by Hanna $\mathrm{P}^{\mathrm{H}}$ meter, model $\mathrm{H} 18417$ equipped with combined glass electrode. The $\mathrm{PH}$ meter readings were converted to hydrogen ion concentration, $\left[\mathrm{H}^{+}\right]$, by means of the Van Uitert relation [5].

Electronic absorption spectra were measured on Perkin-Elmer Lambda 3 spectrophotometer.

For the spectrophotometric determination of the acid dissociation constant, $\mathrm{PKa}$, an aliquot of the stock hydrazone solution was diluted with perchloric acid solution, absolute ethanol and water to give a definite overall ionic strength of $0.1 \mathrm{M}$ and final hydrazone strength of $10-3 \mathrm{M}$ and contain the required ethanol content of $(20 \%, 40 \%$, $60 \%$ and $80 \% \mathrm{v} / \mathrm{v})$. The absorption spectra of each of these solutions were examined in terms of different $\mathrm{PH}$ values and at temperatures of $\left(25^{\circ} \mathrm{C}, 30^{\circ} \mathrm{C}, 35^{\circ} \mathrm{C}, 40^{\circ} \mathrm{C}\right.$ and $\left.45^{\circ} \mathrm{C}\right)$. Temperature was controlled by using a double jacket cell connected to an ultra thermostat adjusted to the required temperature $\left( \pm 0.1^{\circ} \mathrm{C}\right)$. This thermostat is connected, in turn, to the spectrophotometric cell in order to verify the same temperature for both measurements.

Static dielectric constant of each solution was measured on a Dipolemeter DMO1 manufactured by WTW, Germany. Dielectric constant£ density, d, and refractive index, $n_{D}$, for hydrazone solutions were measured at $30^{\circ} \mathrm{C}$ as described earlier [6]. The dipole moments, $\mu_{2}$, in benzene was determined by the refractivity method employing the Debye Equation (1)

$$
\mu_{2}=\left(0.01273 \sqrt{C P_{2 \infty}}-D P_{2}\right) T
$$

where $D_{2}$ is the molar deformation of the solute, obtained by extrapolating the measured molecular refraction for the sodium-D line to infinite wave length [7]; and $P_{2 \infty}$ is the molecular polarization of the solute at infinite dilution, taken as the average of that determined graphically and those calculated by Hedestrand's [8] and Plait-Baneerjee's [9] Equations.

IR spectra were determined for samples in $\mathrm{KBr}$ discs on a Pye Unicam SP3-300.

$1 \mathrm{H}$ NMR spectra were measured in $\mathrm{CDCl} 3$ on a Varian Gimini $200 \mathrm{MHz}$ NMRSpectrophotometer. 


\section{Results and Discussion}

The acid dissociation constants pKa's of the analogues 1 and 2 were determined spectrophotometrically in $20 \%, 40 \%, 60 \%$ and $80 \%(\mathrm{v} / \mathrm{v})$ ethanol-water mixture over the temperature range $25^{\circ} \mathrm{C}$ to $45^{\circ} \mathrm{C}$. The pKa values were calculated from the absorbance, $\mathrm{A}$, and $\mathrm{P}^{\mathrm{H}}$ data, using the Equation (2).

$$
\mathrm{pKa}=\mathrm{pH}+\log (A \max -A) \div(A-A \min )
$$

$A$ max and $A$ min where are the absorbance values in basic and acidic media $(\mathrm{PH}=10$ and $\mathrm{P}^{\mathrm{H}}=1$ ), respectively. The results obtained are given in Table 1 . The values of the dielectric constants of the solvent mixtures, at the working temperature range, $25^{\circ} \mathrm{C}$ $45^{\circ} \mathrm{C}$ are given in Table 2.

The data obtained show that at any given temperature, an increase of ethanol content in the solvent mixture resulted in an increase of the $\mathrm{pKa}$ values, as a consequence of decreasing the dielectric constant of the solvent mixture [10]. Also, for a given solvent mixture, increase of temperature resulted in a decrease of the $\mathrm{pKa}$ values.

Table 1. pKa values of compounds 1 and 2 ( \pm 0.01 unit) in ethanol-water mixture of variant composition and at different temperatures.

\begin{tabular}{|c|c|c|c|c|}
\hline \multicolumn{5}{|c|}{ Compound 1} \\
\hline \multirow{2}{*}{ Temp. ${ }^{\circ} \mathrm{C}$} & \multicolumn{4}{|c|}{ Volume\% of ethanol } \\
\hline & 20 & 40 & 60 & 80 \\
\hline 25 & 7.08 & 7.72 & 8.38 & 9.01 \\
\hline 30 & 7.02 & 7.65 & 8.17 & 8.87 \\
\hline 35 & 6.95 & 7.50 & 8.11 & 8.72 \\
\hline 40 & 6.87 & 7.42 & 7.02 & 8.57 \\
\hline 45 & 6.78 & 7.35 & 7.95 & 8.52 \\
\hline \multicolumn{5}{|c|}{ Compound 2} \\
\hline \multirow{2}{*}{ Temp. ${ }^{\circ} \mathrm{C}$} & \multicolumn{4}{|c|}{ Volume $\%$ of ethanol } \\
\hline & 20 & 40 & 60 & 80 \\
\hline 25 & 7.11 & 7.77 & 8.45 & 9.16 \\
\hline 30 & 7.03 & 7.68 & 8.34 & 9.01 \\
\hline 35 & 6.92 & 7.56 & 8.20 & 8.68 \\
\hline 40 & 6.82 & 7.45 & 8.07 & 8.75 \\
\hline 45 & 6.71 & 7.32 & 7.96 & 8.61 \\
\hline
\end{tabular}

Table 2. Dielectric constant, $\mathcal{E}$, values ( \pm 0.05 units) in ethanol-water mixture of variant composition and at different temperatures.

\begin{tabular}{ccccc}
\hline & \multicolumn{4}{c}{ Volume\% of ethanol } \\
\cline { 2 - 5 } Temp. ${ }^{\circ} \mathrm{C}$ & 20 & 40 & 60 & 80 \\
\hline 25 & 68.93 & 57.72 & 46.45 & 35.40 \\
30 & 65.92 & 54.38 & 43.02 & 32.95 \\
35 & 63.77 & 52.39 & 41.57 & 30.73 \\
40 & 60.51 & 49.56 & 40.05 & 29.94 \\
45 & 57.42 & 46.38 & 38.67 & 28.34 \\
\hline
\end{tabular}


From the data obtained, both the enthalpy, $\Delta H^{\circ}$, and the entropy, $\Delta S^{\circ}$, were calculated using the van't Hoff Equations (3) and (4).

$$
\begin{aligned}
& \mathrm{n} K_{e q}=-\frac{1 \Delta H^{o}}{R T}+\frac{\Delta S^{o}}{R} \\
& \ln \frac{K_{T 2}}{K_{T i}}=\frac{\Delta H^{o}}{R}\left[\frac{1}{T_{1}}-\frac{1}{T_{2}}\right]
\end{aligned}
$$

The results are summarized in Table 3. It is clear that $\Delta H^{o}$ values are positive, whereas the entropy, $\Delta S^{\circ}$, values are negative for all solvent mixtures indicating that the process of ionization is always endothermic whatever the ethyl-water content in the solvent mixture.

Harned et al. [11] investigated the temperature variation of the acidity of acetic acid in water and in aqueous dioxane, as well as the acidity of other acids in water [12] [13]. A parabolic relationship between $\mathrm{pKa}$ and temperature was found; and is given by the Equation (5).

$$
\mathrm{pKa}-\mathrm{pKm}=C(T-\theta)^{2}
$$

where the temperature $\mathrm{T}$, is expressed in degree centigrade, $\mathrm{pKm}$ is the minimum value of pKa, at temperature $\theta$, and $\mathrm{C}$ is an arbitrary constant of the order, $5 \times 10-2$ degree.

When Equation (5) was applied to our experimental data, the values of $\mathrm{pKm}$ and $\theta$ were calculated and situated in Table 4 . The data indicated that, increasing the ethanol content in the solvent mixture increases the value of $\theta$ while decreasing the $\mathrm{pKm}$ values. The increase of $\theta$ values with increasing the ethanol content being in agreement with the above finding that the ionization is opposed by increasing the ethanol content.

Comparison of the pKa values for the compounds 1 and 2 revealed that, replacement of the nitrogen hetero atom in compound 1 by the sulpher atom in compound 2 resulted in a slight increase in the pKa values whatever the working temperature and the solvent composition.

\begin{tabular}{|c|c|c|c|c|}
\hline \multicolumn{5}{|c|}{ Compund 1} \\
\hline \multirow{2}{*}{ Thermodynamic parameter } & \multicolumn{4}{|c|}{ Volume $\%$ of ethanol } \\
\hline & 20 & 40 & 60 & 80 \\
\hline$\Delta H^{o}(\mathrm{~kJ} / \mathrm{mole})( \pm 1)$ & 22.51 & 31.54 & 39.92 & 47.89 \\
\hline$\Delta \mathrm{S}^{\mathrm{o}}(\mathrm{kJ} / \mathrm{mole})( \pm 3)$ & -53.34 & -36.8 & -20.33 & -6.32 \\
\hline \multicolumn{5}{|c|}{ Compund 2} \\
\hline \multirow{2}{*}{ Thermodynamic parameter } & \multicolumn{4}{|c|}{ Volume $\%$ of ethanol } \\
\hline & 20 & 40 & 60 & 80 \\
\hline$\Delta H^{o}(\mathrm{~kJ} / \mathrm{mole})( \pm 1)$ & 31.74 & 39.46 & 44.65 & 65.45 \\
\hline$\Delta \mathrm{S}^{\mathrm{o}}(\mathrm{kJ} / \mathrm{mole})( \pm 3)$ & -24.76 & -0.32 & -7.05 & -5.43 \\
\hline
\end{tabular}

Table 3. Thermodynamic parameters, of dissociation, for the compounds 1 and 2 in ethanolwater, solvent mixture, with different composition. 
Table 4. The calculated $\theta$ and pKm values for compounds 1 and 2 in ethanol-water mixture of different composition.

\begin{tabular}{|c|c|c|c|c|}
\hline \multicolumn{5}{|c|}{ Compund 1} \\
\hline & \multicolumn{4}{|c|}{ Volume $\%$ of ethanol } \\
\hline & 20 & 40 & 60 & 80 \\
\hline$\theta$ & 164.08 & 212.45 & 260.74 & 323.78 \\
\hline $\mathrm{pKm}$ & 6.04 & 5.86 & 5.43 & 4.52 \\
\hline \multicolumn{5}{|c|}{ Compund 2} \\
\hline & \multicolumn{4}{|c|}{ Volume\% of ethanol } \\
\hline & 20 & 40 & 60 & 80 \\
\hline$\theta$ & 212.74 & 261.32 & 291.82 & 323.78 \\
\hline pKm & 5.23 & 4.90 & 4.83 & 4.52 \\
\hline
\end{tabular}

In general, compounds 1 and 2 can be represented by either of the following two structures, (i) and (ii).

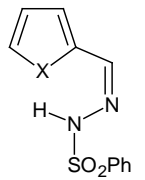

Structure i

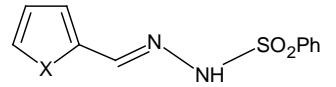

Structure ii

According to the structure (i), it might be expected that the acidity is most likely dependent upon the strength of the intramolecular H-bond, X... H-N, in such a manner that, the stronger the bond the less will be the acidity of the compound. The electronegativity of the hetero atom, $\mathrm{X}$, will affect the strength of the H-bond and hence, the acidity of the H-N group through an inductive effect; that is, the higher the electronegativity of the hetero atom, $\mathrm{X}$, the higher is the acidity of the compound. Referring to the structure (i), the acidity is governed by the predominance of one of the above two effects. On the other hand, the structure (ii) suggests that the acidity is mainly governed by the electronegativity of the hetero atom, $\mathrm{X}$. This means that the greater the electronegativity of, $\mathrm{X}$, the greater will be the inductive effect and hence, the higher the acidity.

Based on the above agreements, structure (ii) seems to be more appropriate for compounds, 1 and 2, than structure (i), since the observed pKa values for the compound, 1, are less than those of compound 2. This conclusion was confirmed by dipole moment for the two compounds in benzene at $30^{\circ} \mathrm{C}$ and comparing the results obtained with those calculated, using the method of bond moments [14], for various possible conformations, Figure 1. The experimental results are given in Table 5, and those calculated for conformations (I-VIII) in Table 6. Comparing the experimental and calculated dipole moment values revealed that the conformation structures II-V, VII and VIII should be excluded, where the calculated dipole moment values are significantly different from the experimental values which are 4.87 and $4.77 \mathrm{D}$ for compounds, 1, and 2, respectively. The calculated dipole moment values, 5.01 and 4.94 for 


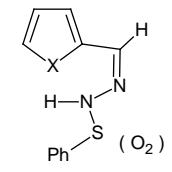

I<smiles></smiles>

V

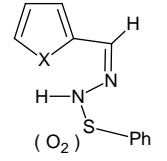

II

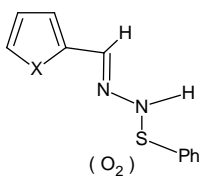

VI<smiles></smiles>

III<smiles></smiles>

VII

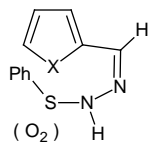

IV

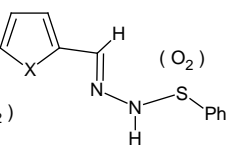

VIII

Figure 1. Various hypothetical conformations for compounds 1 and 2.

Table 5. Dipole moment and polarization data for compounds, 1 , and 2 in benzene at $30^{\circ} \mathrm{C}$.

\begin{tabular}{|c|c|c|c|c|c|c|}
\hline \multirow{2}{*}{ Compd. } & \multicolumn{2}{|c|}{${ }_{\mathrm{D}} \mathrm{P}_{2}$} & \multicolumn{2}{|c|}{$\mathrm{P}_{2 \infty}\left(\mathrm{Cm}^{3}\right)$} & \multirow{2}{*}{$\mathrm{P}_{2 \infty}$} & \multirow{2}{*}{$\mu$} \\
\hline & $\mathrm{Cm}^{3}$ & Graph. & Hedstrand & Palit-Banerjee & & \\
\hline \multirow[t]{3}{*}{1} & 68.9 & 563.76 & 563.81 & 555.47 & 561.01 & 4.92 \\
\hline & & & $\alpha=10.717$ & $\mathrm{~A}=0.342$ & & \\
\hline & & & $\beta=0.304$ & $\gamma=1.862$ & & \\
\hline \multirow[t]{3}{*}{2} & 70.15 & 536.43 & 536.49 & 527.18 & 533.37 & 4.77 \\
\hline & & & $\alpha=9.504$ & $\mathrm{~A}=0.342$ & & \\
\hline & & & $\beta=0.191$ & $\gamma=1.640$ & & \\
\hline
\end{tabular}

Table 6. Calculated dipole moment values for various conformations (I-VIII) of compounds 1 and 2 .

\begin{tabular}{ccccccccc}
\hline & \multicolumn{8}{c}{ Conformations } \\
\cline { 2 - 9 } Compd. & I & II & III & IV & V & VI & VII & Viii \\
\hline & 5.01 & 3.50 & 2.87 & 2.96 & 3.50 & 4.93 & 3.03 & 2.66 \\
2 & 4.94 & 3.49 & 3.00 & 2.88 & 3.39 & 4.85 & 2.38 & 1.98 \\
\hline
\end{tabular}

compounds, 1 and 2, respectively are close to the calculated value based on conformation VI.

The non-chelated structure (ii) was further confirmed by the observation that no metal complex could be detected spectrophotometrically with both compounds, 1 and 2, where, all trials made to prepare Fe III, Co II, Ni II and Cu II complexes were failed.

The IR and $1 \mathrm{H}$ NMR spectra of the two compounds were compared with that of benzaldehyde benzenesulphonylhydrazone, 3 . The stretching frequencies, $v \mathrm{NH}$, and the proton chemical shift, $\delta \mathrm{NH}$, of the N-H proton of compounds, $1-3$, are given in Table 7. 
Table 7. Chemical shifts of N-H proton, $\delta \mathrm{NH}$, and N-H stretching frequencies, $v \mathrm{NH}$ for compounds $1-3$.

\begin{tabular}{ccc}
\hline Compound & $\delta \mathrm{NH}(\mathrm{ppm})$ & $\downarrow \mathrm{NH}\left(\mathrm{Cm}^{-1}\right)$ \\
\hline 1 & 8.25 & 3190 \\
2 & 8.35 & 3160 \\
3 & 8.44 & 3180 \\
\hline
\end{tabular}

The close similarity of the stretching frequencies of $\mathrm{NH}$ bond and the chemical shift values of the three compounds (1 - 3), substantiate further our previous conclusion that compounds 1 and 2 exist in a non-chelated form.

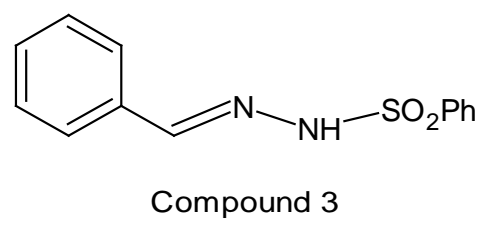

\section{Conclusion}

Based on determined acid dissociation constant values, $\mathrm{pKa}$, for the two compounds 1 and 2 and the electronegativity of the hetero atom, $\mathrm{X}$, structure (ii), which is the non chelated form, seems to be more appropriate for these compounds. This was also confirmed through comparing the experimentally determined dipole moment values of the two compounds with the calculated values obtained of different conformation structures. Also, these compounds failed to form complexes with Fe III, Co II, Ni II and Cu II, metalions.

\section{References}

[1] Grammaticakis, P. (1952) Bulletin de la Société Chimique de France, 446.

[2] Nincham, A.W. (1955) The Chemistry of Formazans and Tetrazolium Salts. Chemical Reviews, 55, 355-483. http://dx.doi.org/10.1021/cr50002a004

[3] Yao, H.C. and Resnick, P. (1962) Azo-Hydrazone Conversion. I. The Japp-Klingemann Reaction. Journal of the American Chemical Society, 84, 3514-3517. http://dx.doi.org/10.1021/ja00877a018

[4] Shawali, A.S., Fahmi, A.A. and Eweiss, N.F. (1979) Azo Coupling of Benzenesulfonylhydrazones of Heterocyclic Aldehydes. Journal of Heterocyclic Chemistry, 16, 123-128. http://dx.doi.org/10.1002/jhet.5570160123

[5] Van Uitert, L.G. and Hass, C.G. (1953) Studies on Coördination Compounds. I. A Method for Determining Thermodynamic Equilibrium Constants in Mixed Solvents. Journal of the American Chemical Society, 75, 451-455. http://dx.doi.org/10.1021/ja01098a057

[6] Turkey, A.R., Rizk, H.A. and Girgis, Y.M. (1960) The Dielectric Properties of Mercuric Chloride and Mercuric Bromide in Dioxane. Journal of Physical Chemistry, 64, 565-567. http://dx.doi.org/10.1021/j100834a013

[7] Bottcher, C.J.F., Zhan, C.T. and Miles, J.B. (1952) Theory of Electric Polarization. Elsevier, 
Houston.

Zahn, C.T. and Miles Jr., J.B. (1928) The Dielectric Constant and the Electric Moment of CO, COS, $\mathrm{CS}_{2}$, and $\mathrm{H}_{2}$ S. Physical Review, 32, 497. http://dx.doi.org/10.1103/PhysRev.32.497

[8] Hedstrand, G.Z. (1929) Physical Chemistry, 2B, 424.

[9] Palit, S.R. and Banerjee, B.C. (1951) Calculation of Polarization and Dipole Moment from Solution Data. Transactions of the Faraday Society, 47, 1299-1304. http://dx.doi.org/10.1039/tf9514701299

[10] El-Harkany, A.A., Hafez, A.M. and Khadr, A.M. (1982) Study of the Dissociation Constants of Some Weak Indicator Bases in DMSO+Water Solvent Mixtures. Journal of Electroanalytical Chemistry and Interfacial Electrochemistry, 132, 345-355. http://dx.doi.org/10.1016/0022-0728(82)85030-4

[11] Harned, H.S. and Echlers, R.W. (1933) The Dissociation Constant of Acetic Acid from 0 to $60^{\circ}$ Centigrade. Journal of the American Chemical Society, 55, 652-656. http://dx.doi.org/10.1021/ja01329a027

[12] Harned, H.S. and Kazanjian, L. (1936) The Ionization Constant of Acetic Acid in Dioxane-Water Mixtures. Journal of the American Chemical Society, 58, 1912-1915. http://dx.doi.org/10.1021/ja01301a023

[13] Harned, H.S. and Embrec, N.D. (1934) The Temperature Variation of Ionization Constants in Aqueous Solutions. Journal of the American Chemical Society, 56, 1050. http://dx.doi.org/10.1021/ja01320a013

[14] Naoum, M.M. and Rizk, H.A. (1982) Indian Journal of Chemistry, 21A, 220.

\section{Submit or recommend next manuscript to SCIRP and we will provide best service for you:}

Accepting pre-submission inquiries through Email, Facebook, LinkedIn, Twitter, etc. A wide selection of journals (inclusive of 9 subjects, more than 200 journals)

Providing 24-hour high-quality service

User-friendly online submission system

Fair and swift peer-review system

Efficient typesetting and proofreading procedure

Display of the result of downloads and visits, as well as the number of cited articles Maximum dissemination of your research work

Submit your manuscript at: http://papersubmission.scirp.org/

Or contact ns@scirp.org 